\title{
Effect of Temperature on the Performance of Limestone/Sandstone Filters Treating Landfill Leachate
}

\author{
${ }^{1}$ A.E. Ghaly, ${ }^{1}$ M.A. Kamal and ${ }^{2}$ R. Cote \\ ${ }^{1}$ Department of Process Engineering and Applied Science \\ ${ }^{2}$ School for Resources and Environmental Studies, Dalhousie University, P.O. 1000 \\ Halifax, Nova Scotia, Canada, B3J 2X4
}

\begin{abstract}
The ability of limestone and limestone/sandstone filters to remove dissolved iron and manganese from landfill leachate under field conditions were investigated. The results showed that the precipitation of iron and manganese were affected by temperature and time. Most of iron was removed from solution within the first $10 \mathrm{~min}$ at $20^{\circ} \mathrm{C}$ while the removal of iron from solution took much longer time $(50 \mathrm{~min})$ at $5^{\circ} \mathrm{C}$. Larger percentage $(69 \%)$ of manganese was removed from solution within the first $20 \mathrm{~min}$ at $20^{\circ} \mathrm{C}$ compared to that $(42 \%)$ removed at $5^{\circ} \mathrm{C}$. Removal of manganese from solution was affected by the presence of iron while presence of manganese did not affect iron removal from solution. The lower removal efficiencies of manganese showed the slow kinetic of manganese oxidation. The iron and manganese removal rate constants of the limestone filters were higher than those of the limestone/sandstone filters. The $\mathrm{pH}$ of the water samples did not exceed 7.7. Therefore, the wetland ecosystem should be able to adjust to water having a slight alkalinity without suffering adverse effects.
\end{abstract}

Key words: Landfill leachate, iron, manganese, limestone, sandstone, filter

\section{INTRODUCTION}

Landfill leachate is one of the main environmental concerns associated with landfill management because of its potential to damage the quality of both the ground and surface waters ${ }^{[1]}$. Contaminants in leachate include organic matter, heavy metals and mineral oils. However, the chemical composition of leachate varies greatly depending on the age of landfill and the events prior to the time of sampling which include the distribution of the organic components in landfill, the availability of nutrients, the moisture content of waste, moisture routing through the fill and the degree of initial compaction ${ }^{[2,3]}$.

Conventional water treatment systems that remove iron and manganese from wastewater involve the addition of alkaline chemicals (such as lime, sodium hydroxide and sodium carbonate) to the water. Alkali addition causes the $\mathrm{pH}$ of the water to increase and the dissolved metals to precipitate out of solution. These active systems usually have increased costs associated with their operation and maintenance, purchase of chemicals and disposal of metal laden sludge ${ }^{[4,5]}$. However, passive treatment systems that use limestone have become very popular for treating landfill leachates and mine drainage because these systems are inexpensive to construct and maintain and limestone is a cheap source of alkalinity ${ }^{[6,7]}$. Kamal ${ }^{[8]}$ conducted a laboratory study to evaluate the effectiveness of limestone filters in removing iron and manganese from landfill leachates under ambient temperature and found that most of these elements were removed from solution by precipitation within the first two hours. However, the effect of outdoor temperature variation on the precipitation of these metals must be investigated before a field scale filter is designed and constructed. The average water temperatures in Atlantic Canada fluctuate between 5 and 20 degrees during the months of March and November.

The aim of this study was to evaluate the effectiveness of limestone and limestone/sandstone filters in removing dissolved iron and manganese from a landfill leachate under field conditions. The specific objectives were: (a) to evaluate the impact of temperature variation $\left(5-20^{\circ} \mathrm{C}\right)$ on the removal efficiencies of iron and manganese by limestone and limestone/sandstone filters, (b) to calculate the specific removal rates for $\mathrm{Fe}$ and $\mathrm{Mn}$ and (c) to determine the suitability of the treated wastewater for wetland aquatic life as measured by its final $\mathrm{pH}$.

\section{MATERIALS AND METHODS}

\section{Experimental apparatus}

The experimental setup shown in Fig. 1 consisted of six holding beakers each had a $12.5 \mathrm{~cm}$ diameter and a 15 $\mathrm{cm}$ height. Three beakers received limestone while the other three beakers received a mixture of limestone and

Corresponding Author: $\quad$ A.E. Ghaly, Process Engineering and Applied Science Department, Dalhousie University, Halifax, Nova Scotia, Canada B3J 2X4, Email: abdel.ghaly@dal.ca, Tel: (902)494-6014, Fax: (902)4232423 
sandstone of 1:1 ratio. An aeration unit was installed at the bottom of each beaker. The air was provided from the main laboratory air supply to a manifold with six outlets. Each outlet was connected to a pressure regulator (Model 129121/510, ARO, Bryan, Ohio), which was connected to the aerator located in each holding beaker. Tygon tubing of $0.75 \mathrm{~cm}$ outside diameter was used to connect the main air supply, manifold and aeration unit.

\section{Preparation of leachate}

The two heavy metals investigated in this study were iron and manganese. Contaminated water solutions were prepared using ferrous ammonium sulfate hexahydrate $\left(\mathrm{Fe}\left(\mathrm{NH}_{4}\right)_{2}\left(\mathrm{SO}_{4}\right)_{2} \cdot 6 \mathrm{H}_{2} \mathrm{O}\right)$ and manganese sulfate monohydrate $\left(\mathrm{MnSO}_{4} \bullet \mathrm{H}_{2} \mathrm{O}\right)$. They were purchased as reagent grade chemicals from Fisher Scientific, Ottawa, Ontario. Each chemical was dissolved in tap water which produced solutions with an iron concentration of $6.6 \mathrm{mg} \mathrm{L}^{-1}$, a manganese concentration of $1.8 \mathrm{mg} \mathrm{L}^{-1}$ and an iron/manganese solution of $6.6 / 1.8 \mathrm{mg} \mathrm{L}^{-1}$ as shown in Table 1 .

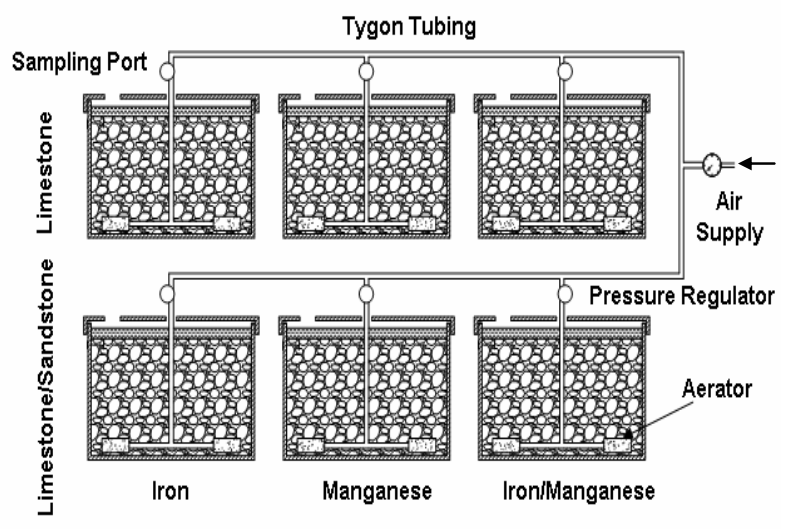

Fig. 1: Experimental setup

Table 1: Concentrations of elements present in the synthetic landfill leachate

\begin{tabular}{lc}
\hline Element & Synthetic Landfill Leachate $\left(\mathrm{mg} \mathrm{L}^{-1}\right)$ \\
\hline Tap Water & 0.069 \\
Aluminum & $<0.002$ \\
Arsenic & 7.000 \\
Chloride & 0.010 \\
Copper (Total) & 0.060 \\
Fluoride & $<0.500$ \\
Lead $\left(\mu \mathrm{g} \mathrm{L}^{-1}\right)$ & $<0.050$ \\
Mercury & 0.060 \\
Nitrate-Nitrogen & 8.000 \\
Sodium & 11.800 \\
Sulfate & 0.072 \\
Zinc (Total) & \\
Regent Added & 6.60 \\
Iron & \\
or & 1.80 \\
Manganese & \\
or & 6.60 \\
Iron (and) & 1.80 \\
Manganese & \\
\hline
\end{tabular}

\section{Experimental procedures}

Three beakers were filled with limestone $(2.024 \mathrm{~kg})$ while the other three beakers were filled with a mixture of limestone $(1.012 \mathrm{~kg})$ and sandstone $(1.012 \mathrm{~kg})$, each to a height of $15 \mathrm{~cm}$. A $0.9 \mathrm{~L}$ iron solution $\left(6.6 \mathrm{mg} \mathrm{L}^{-1}\right)$ was poured into each of the first set of two beakers, a $0.9 \mathrm{~L}$ manganese solution $\left(1.8 \mathrm{mg} \mathrm{L}^{-1}\right)$ was poured into each of the second set of two beakers and a $0.9 \mathrm{~L}$ iron/manganese solution (6.6 and $1.8 \mathrm{mg} \mathrm{L}^{-1}$ ) was poured into each of the third set of two beakers. The pressure regulator on the aeration system was adjusted to provide an aeration rate of $7 \mathrm{~cm}^{3} \mathrm{~min}^{-1}$. The experiment was conducted for $3 \mathrm{hrs}$ under four different temperatures $\left(5,10,15\right.$ and $\left.20^{\circ} \mathrm{C}\right)$. A total of 24 beakers were used in this study. The experiment was replicated three times.

Water samples of $5 \mathrm{~mL}$ were collected from each beaker at $2.5,5,7.5,10,20,30,40,50,60,80,100$, $120,150,180 \mathrm{~min}$ and were immediately stored in the freezer to slow the iron oxidation reactions. The samples were analyzed for iron and manganese using a spectrophotometer (Model DR/2500, HACH Company, Loveland, CO, USA). The FerroVer ${ }^{\circledR}$ Method (Method 8008) was used to measure total iron and the Periodate Oxidation Method (Method 8034) was used to measure manganese. The $\mathrm{pH}$ of the samples was also measured using a pH meter (Model 805MP, Fisher Scientific, Montreal, Quebec, Canada).

\section{RESULTS AND DISCUSSION}

Figure 2 -7 present the changes in the $\mathrm{pH}$ and the iron and manganese concentrations in the wastewater over time. Table 2 and 3 show the removal efficiencies of iron and manganese.

\section{Iron}

The iron concentrations in the water samples obtained from the limestone filters after $3 \mathrm{hrs}$ were 0.02, 0.07, 0.23 and $0.23 \mathrm{mg} \mathrm{L}^{-1}$ with average removal efficiencies of $99.77,98.94,96.52$ and $96.52 \%$ for the temperatures of $20,15,10$ and $5^{\circ} \mathrm{C}$, respectively. The iron concentrations in the water samples obtained from the limestone/sandstone filters after $3 \mathrm{hrs}$ were $0.05,0.07$, 0.23 and $0.34 \mathrm{mg} \mathrm{L}^{-1}$ with average removal efficiencies of $99.32,98.94,96.52$ and $94.85 \%$ for the temperatures of $20,15,10$ and $5^{\circ} \mathrm{C}$, respectively. Removal of iron from the solution containing iron and manganese was similar to that of the solution containing iron alone for both the limestone and the limestone/sandstone filters.

The iron removal efficiency decreased as the temperature decreased. Most of iron was removed from solution within the first $10 \mathrm{~min}$ at $20^{\circ} \mathrm{C}$ while the removal of iron from solution at $5^{\circ} \mathrm{C}$ took much longer time. However, by the end of the experiment $(180 \mathrm{~min})$ the difference in iron removal due to the effect of temperature $\left(20^{\circ} \mathrm{C}\right.$ vs. $\left.5^{\circ} \mathrm{C}\right)$ was approximately $4.92 \%$. 


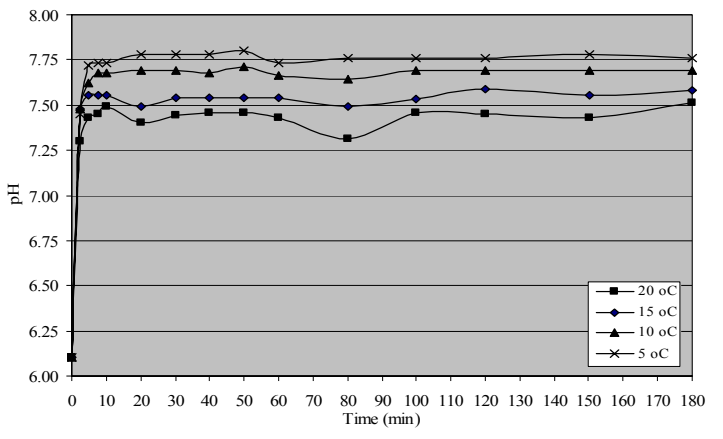

(a) $\mathrm{pH}$

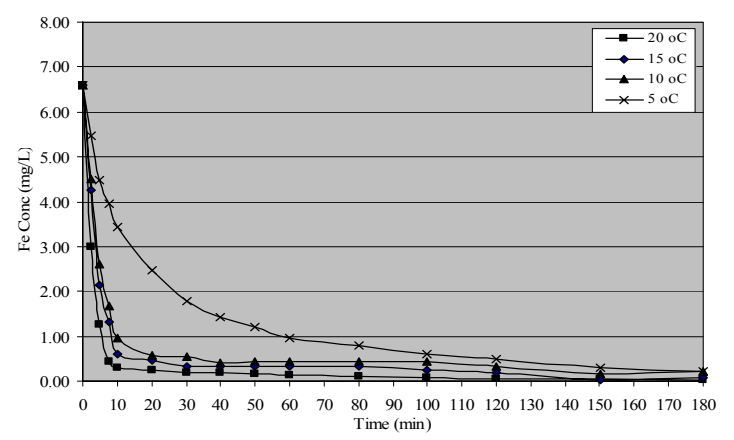

(b) Iron

Fig. 2: $\mathrm{pH}$ and iron concentrations of water obtained from the limestone filter treating manganese free wastewater

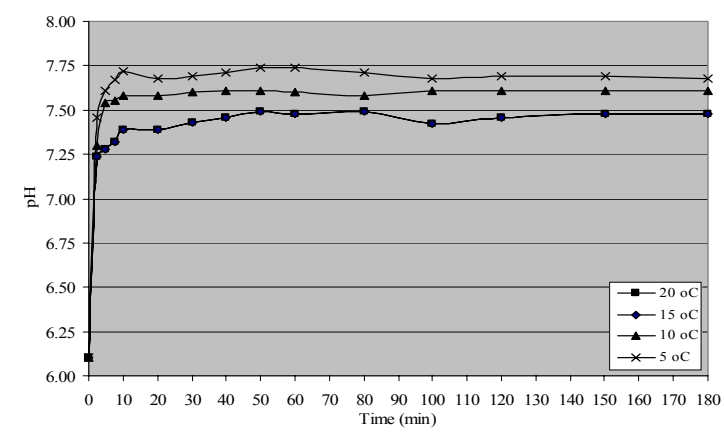

(a) $\mathrm{pH}$

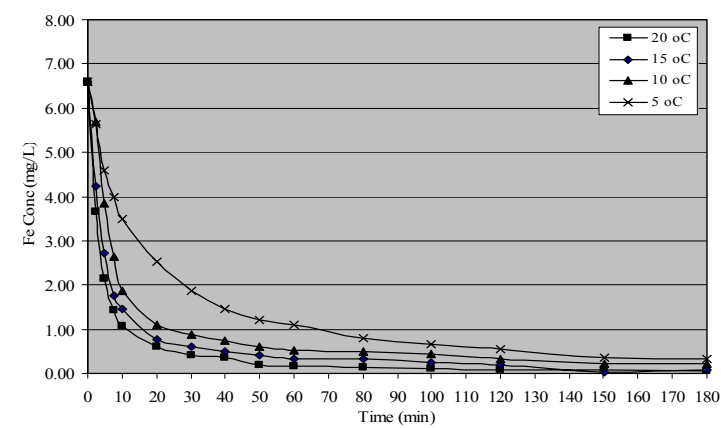

(b) Iron

Fig. 3: $\mathrm{pH}$ and iron concentrations of water obtained from the limestone/sandstone filter treating manganese free wastewater

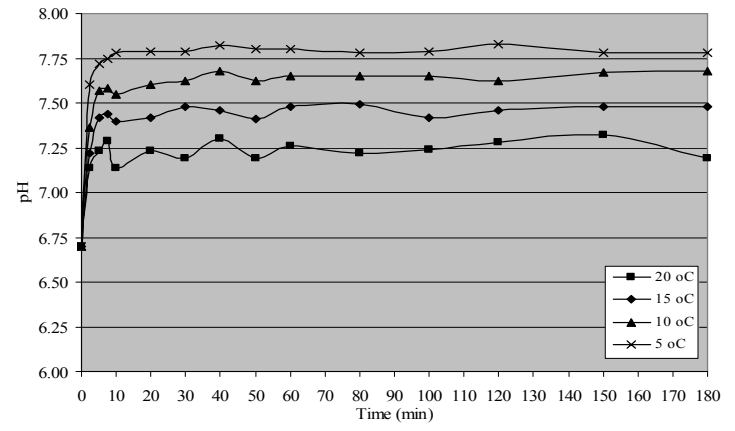

(a) $\mathrm{pH}$

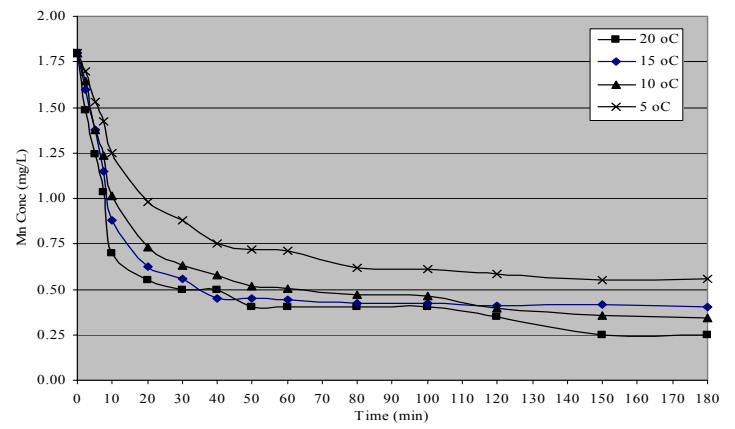

(b) Manganese

Fig. 4: $\mathrm{pH}$ and manganese concentrations of water obtained from the limestone filter treating iron free wastewater

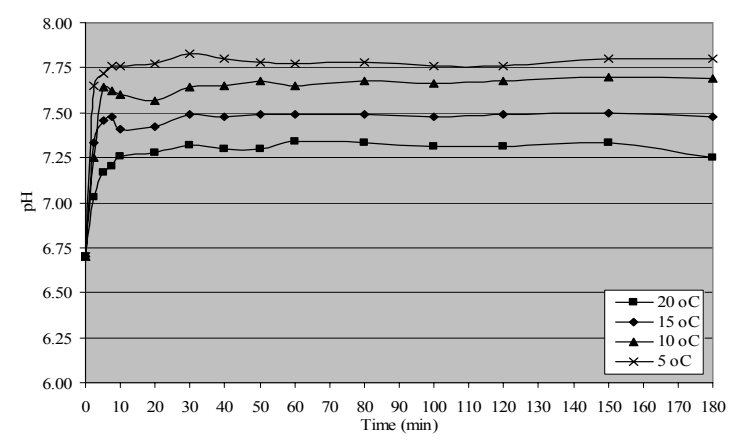

(a) $\mathrm{pH}$

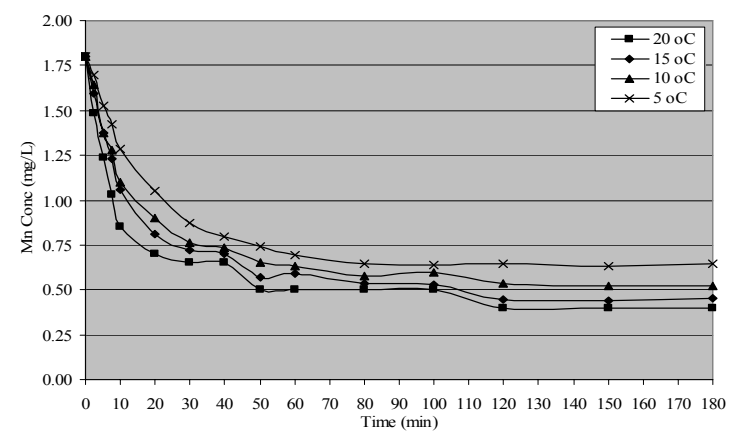

(b) Manganese

Fig. 5: $\mathrm{pH}$ and manganese concentrations of water obtained from the limestone/sandstone filter treating iron free wastewater 


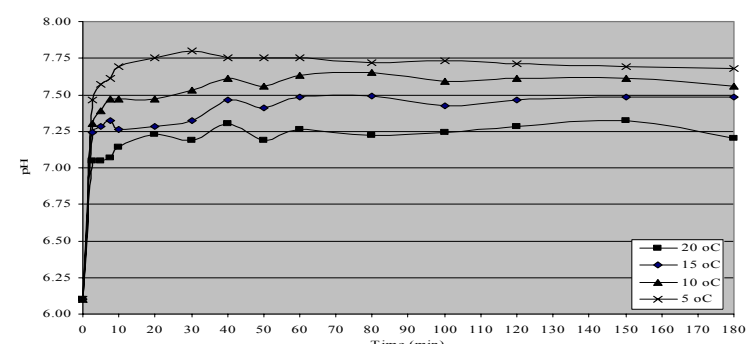

(a) $\mathrm{pH}$

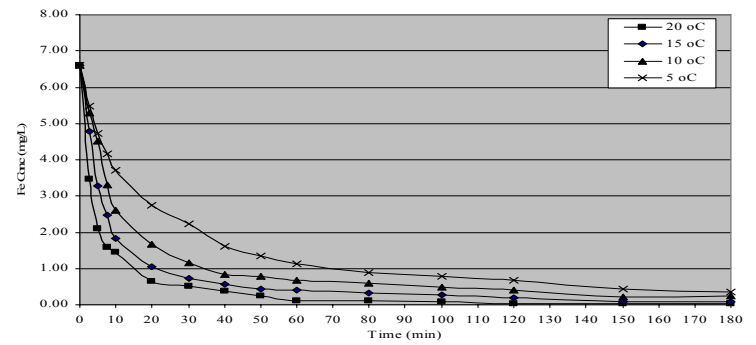

(b) Iron

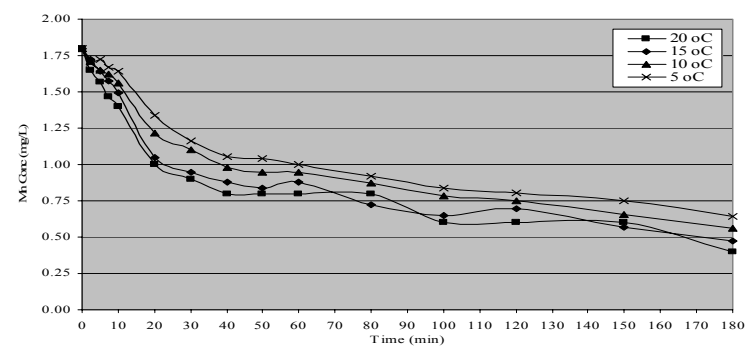

(c) Manganese

Fig. 6: $\mathrm{pH}$ and iron and manganese concentrations of water obtained from the limestone/sandstone filter treating $\mathrm{Fe}$ and $\mathrm{Mn}$ containing wastewater

These results are very useful when designing the field filters because the runoff during the winter is slower and the temperature of the water is lower, compared to those during the summer, thus requiring a longer retention time for iron removal.

Iron usually drains from landfills in the reduced ferrous form $\left(\mathrm{Fe}^{2+}\right)$. At a $\mathrm{pH}$ greater than 3.5 with oxygen present, ferrous iron will oxidize to ferric iron as follows ${ }^{[5]}$ :

$4 \mathrm{Fe}^{2+}{ }_{(\mathrm{aq})}+\mathrm{O}_{2(\mathrm{~g})}+4 \mathrm{H}^{+}{ }_{(\mathrm{aq})} \rightarrow 4 \mathrm{Fe}^{3+}{ }_{(\mathrm{aq})}+2 \mathrm{H}_{2} \mathrm{O}_{(\mathrm{l})}$

Ferric iron forms iron hydroxide $\left(\mathrm{Fe}(\mathrm{OH})_{3}\right)$ precipitate as a result of hydroxylation $\left(\mathrm{Fe}^{3+}\right.$ reacting with $\mathrm{H}_{2} \mathrm{O}$ molecules) as follows ${ }^{[9]}$ :

$\mathrm{Fe}^{3+}{ }_{(\mathrm{aq})}+3 \mathrm{H}_{2} \mathrm{O}_{(\mathrm{l}) \rightarrow} \mathrm{Fe}(\mathrm{OH})_{3(\mathrm{~s})}+3 \mathrm{H}^{+}{ }_{\text {(aq) }}$ (Acidity)

Cravotta and Trahan ${ }^{[6]}$ indicated that the oxidation of iron in surface waters can be described by the following differential rate expression:

$\mathrm{dC} / \mathrm{dt}=\mathrm{K} \mathrm{C}$

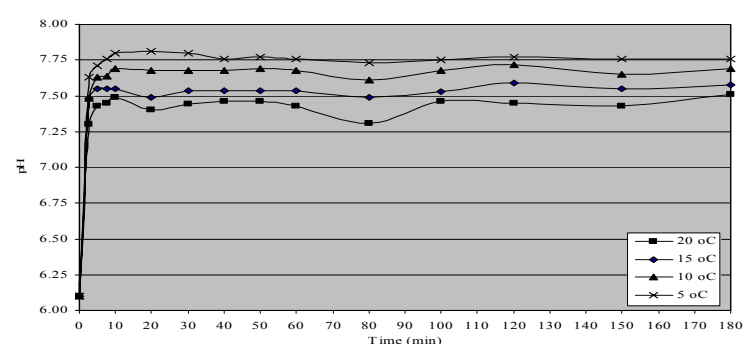

(a) $\mathrm{pH}$

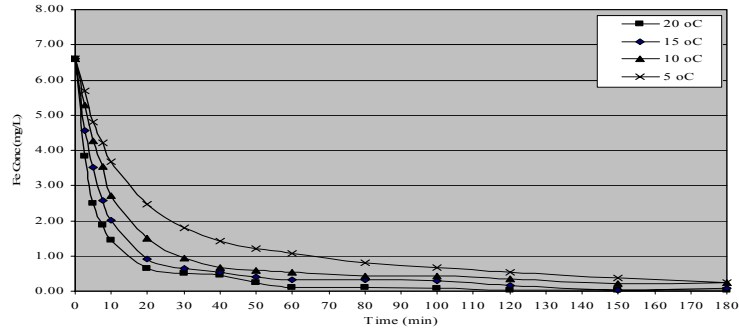

(b) Iron

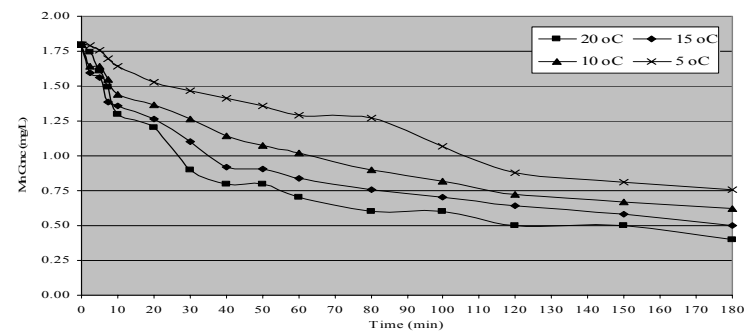

(c) Manganese

Fig. 7: $\mathrm{pH}$ and iron and manganese concentrations of water obtained from the limestone/sandstone filter treating $\mathrm{Fe}$ and $\mathrm{Mn}$ containing wastewater

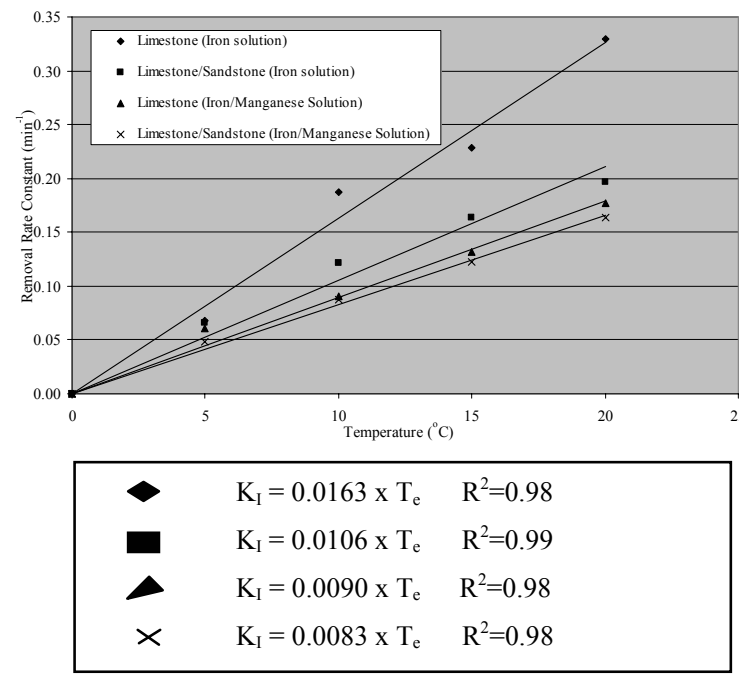

Fig. 8: Effect of temperature on iron removal rate constants

Where:

$\mathrm{C}=$ Element concentration in the solution $\left(\mathrm{mg} \mathrm{L}^{-1}\right)$

$\mathrm{K}=$ Oxidation rate constant $\left(\mathrm{min}^{-1}\right)$ 
Am. J. Environ. Sci., 3 (1): 11-18, 2007

Table 2: $\quad$ Iron removal efficiency (\%)

\begin{tabular}{|c|c|c|c|c|c|c|c|c|c|c|c|c|c|c|c|c|}
\hline \multirow{3}{*}{ Time } & \multicolumn{8}{|c|}{ Mn free wastewater } & \multicolumn{8}{|c|}{ Mn containing wastewater } \\
\hline & \multicolumn{2}{|c|}{$20^{\circ} \mathrm{C}$} & \multicolumn{2}{|c|}{$15^{\circ} \mathrm{C}$} & \multicolumn{2}{|c|}{$10^{\circ} \mathrm{C}$} & \multicolumn{2}{|c|}{$5^{\circ} \mathrm{C}$} & \multicolumn{2}{|c|}{$20^{\circ} \mathrm{C}$} & \multicolumn{2}{|c|}{$15^{\circ} \mathrm{C}$} & \multicolumn{2}{|c|}{$10^{\circ} \mathrm{C}$} & \multicolumn{2}{|c|}{$5^{\circ} \mathrm{C}$} \\
\hline & LF & LSF & LF & LSF & LF & LSF & LF & LSF & LF & LSF & LF & LSF & LF & LSF & LF & LSF \\
\hline 2.5 & 54.55 & 44.55 & 35.30 & 36.06 & 31.67 & 13.94 & 16.97 & 14.70 & 47.58 & 41.67 & 27.58 & 30.91 & 20.00 & 20.00 & 16.97 & 13.64 \\
\hline 5 & 80.76 & 67.42 & 67.58 & 58.79 & 60.30 & 41.82 & 31.97 & 30.45 & 68.33 & 61.97 & 50.45 & 46.67 & 31.67 & 35.45 & 28.33 & 27.27 \\
\hline 7.5 & 93.48 & 78.48 & 80.00 & 73.48 & 74.55 & 60.15 & 40.00 & 39.39 & 75.91 & 71.36 & 62.73 & 60.76 & 50.15 & 46.36 & 37.12 & 36.06 \\
\hline 10 & 95.45 & 83.71 & 90.91 & 77.88 & 85.45 & 71.82 & 47.73 & 46.97 & 77.88 & 77.88 & 72.27 & 69.39 & 60.61 & 58.79 & 43.79 & 44.39 \\
\hline 20 & 96.29 & 90.68 & 92.88 & 88.48 & 91.21 & 83.33 & 62.42 & 61.67 & 90.15 & 90.15 & 84.09 & 86.21 & 74.85 & 77.27 & 58.64 & 62.42 \\
\hline 30 & 96.97 & 93.71 & 95.00 & 90.91 & 91.82 & 86.67 & 72.73 & 71.82 & 92.12 & 92.12 & 88.94 & 90.15 & 82.58 & 85.91 & 66.36 & 72.73 \\
\hline 40 & 97.12 & 94.70 & 94.85 & 92.58 & 93.94 & 88.94 & 78.48 & 77.73 & 94.39 & 93.03 & 91.52 & 91.82 & 87.42 & 89.85 & 75.76 & 78.48 \\
\hline 50 & 97.58 & 97.05 & 95.00 & 93.94 & 93.18 & 90.91 & 81.82 & 81.52 & 96.21 & 96.21 & 93.33 & 93.94 & 88.18 & 91.06 & 79.70 & 81.82 \\
\hline 60 & 97.88 & 97.65 & 95.00 & 95.00 & 93.48 & 92.12 & 85.45 & 83.33 & 98.18 & 98.18 & 93.94 & 95.00 & 90.00 & 91.97 & 83.03 & 83.79 \\
\hline 80 & 98.18 & 97.95 & 95.00 & 95.00 & 93.48 & 92.58 & 87.88 & 87.88 & 98.33 & 98.33 & 95.00 & 95.00 & 90.91 & 93.48 & 86.67 & 87.88 \\
\hline 100 & 98.64 & 98.18 & 96.06 & 96.06 & 93.48 & 93.48 & 90.91 & 90.00 & 98.79 & 98.79 & 96.06 & 95.45 & 92.58 & 93.48 & 88.18 & 89.85 \\
\hline 120 & 99.02 & 98.56 & 96.97 & 96.97 & 95.00 & 94.85 & 92.42 & 91.82 & 99.39 & 99.39 & 96.97 & 97.73 & 93.94 & 94.70 & 90.00 & 91.82 \\
\hline 150 & 99.32 & 98.86 & 99.55 & 99.55 & 97.42 & 96.67 & 95.45 & 94.39 & 99.39 & 99.39 & 98.94 & 99.55 & 96.67 & 96.67 & 93.33 & 94.39 \\
\hline 180 & 99.77 & 99.32 & 98.94 & 98.94 & 96.52 & 96.52 & 96.52 & 94.85 & 99.70 & 99.70 & 98.94 & 99.00 & 96.52 & 96.40 & 94.85 & 96.01 \\
\hline
\end{tabular}

Table 3: $\quad$ Manganese removal efficiency (\%)

\begin{tabular}{|c|c|c|c|c|c|c|c|c|c|c|c|c|c|c|c|c|}
\hline \multirow{3}{*}{ Time } & \multicolumn{8}{|c|}{$\mathrm{Fe}$ free wastewater } & \multicolumn{8}{|c|}{ Fe containing wastewater } \\
\hline & \multicolumn{2}{|c|}{$20^{\circ} \mathrm{C}$} & \multicolumn{2}{|c|}{$15^{\circ} \mathrm{C}$} & \multicolumn{2}{|c|}{$10^{\circ} \mathrm{C}$} & \multicolumn{2}{|c|}{$5^{\circ} \mathrm{C}$} & \multicolumn{2}{|c|}{$20^{\circ} \mathrm{C}$} & \multicolumn{2}{|c|}{$15^{\circ} \mathrm{C}$} & \multicolumn{2}{|c|}{$10^{\circ} \mathrm{C}$} & \multicolumn{2}{|c|}{$5^{\circ} \mathrm{C}$} \\
\hline & LF & LSF & LF & LSF & LF & LSF & LF & LSF & LF & LSF & LF & LSF & LF & LSF & LF & LSF \\
\hline 2.5 & 17.44 & 17.44 & 11.39 & 11.39 & 8.67 & 8.67 & 5.67 & 5.67 & 8.56 & 3.22 & 4.22 & 11.39 & 5.17 & 8.67 & 5.67 & 0.67 \\
\hline 5 & 31.11 & 31.11 & 23.44 & 23.44 & 23.44 & 23.44 & 15.06 & 15.06 & 12.78 & 10.83 & 8.67 & 13.33 & 8.39 & 8.61 & 4.44 & 2.22 \\
\hline 7.5 & 42.61 & 42.61 & 36.22 & 31.78 & 31.50 & 28.89 & 21.11 & 21.11 & 18.44 & 17.22 & 12.44 & 22.94 & 9.94 & 14.06 & 7.11 & 5.78 \\
\hline 10 & 61.11 & 52.78 & 51.11 & 41.28 & 43.61 & 38.83 & 30.50 & 28.61 & 22.22 & 27.78 & 17.00 & 24.44 & 13.17 & 20.00 & 8.89 & 8.61 \\
\hline 20 & 69.44 & 61.11 & 65.44 & 55.00 & 59.39 & 50.06 & 45.61 & 41.61 & 44.44 & 33.33 & 42.00 & 29.67 & 32.33 & 24.22 & 25.61 & 15.33 \\
\hline 30 & 72.22 & 63.89 & 69.11 & 60.00 & 64.78 & 57.78 & 51.33 & 51.33 & 50.00 & 50.00 & 47.28 & 38.89 & 38.72 & 29.67 & 35.56 & 18.50 \\
\hline 40 & 72.22 & 63.89 & 74.83 & 60.94 & 67.78 & 59.22 & 58.39 & 55.56 & 55.56 & 55.56 & 51.11 & 49.06 & 45.39 & 36.67 & 41.28 & 21.67 \\
\hline 50 & 77.78 & 72.22 & 74.83 & 68.33 & 71.44 & 63.78 & 60.00 & 58.83 & 55.56 & 55.56 & 53.61 & 49.72 & 47.33 & 40.44 & 42.22 & 24.44 \\
\hline 60 & 77.78 & 72.22 & 75.56 & 67.28 & 72.11 & 64.83 & 60.61 & 61.33 & 55.56 & 61.11 & 51.11 & 53.33 & 47.61 & 43.33 & 44.44 & 28.39 \\
\hline 80 & 77.78 & 72.22 & 76.50 & 70.11 & 73.83 & 68.00 & 65.56 & 64.11 & 55.56 & 66.67 & 60.00 & 57.78 & 51.44 & 50.00 & 48.89 & 29.33 \\
\hline 100 & 77.78 & 72.22 & 76.50 & 70.44 & 74.17 & 66.94 & 66.22 & 64.44 & 66.67 & 66.67 & 63.78 & 60.83 & 56.56 & 54.50 & 53.33 & 40.78 \\
\hline 120 & 80.56 & 77.78 & 77.17 & 75.06 & 78.17 & 70.11 & 67.67 & 64.11 & 66.67 & 72.22 & 61.33 & 64.44 & 58.50 & 60.00 & 55.28 & 51.11 \\
\hline 150 & 86.11 & 77.78 & 76.83 & 75.56 & 80.22 & 70.83 & 69.39 & 64.83 & 66.67 & 72.22 & 68.33 & 67.83 & 63.61 & 62.78 & 58.50 & 55.11 \\
\hline 180 & 86.11 & 77.78 & 77.78 & 74.67 & 80.89 & 70.83 & 68.89 & 64.11 & 77.78 & 77.78 & 73.61 & 72.28 & 68.89 & 65.61 & 64.44 & 58.00 \\
\hline
\end{tabular}

Equation (3) on integration yield the following exponential equation:

$$
\mathrm{C}_{\mathrm{Fet}}=\mathrm{C}_{\mathrm{Fei}} \mathrm{e}^{-\mathrm{KI} \mathrm{t}}
$$

Where:

$\mathrm{C}_{\mathrm{Fet}}=$ Iron concentration at time $\mathrm{t}\left(\mathrm{mg} \mathrm{L}^{-1}\right)$

$\mathrm{C}_{\mathrm{Fei}}=$ Iron initial concentration $\left(\mathrm{mg} \mathrm{L}^{-1}\right)$

The experimental data was fitted to Equation (4) and the iron removal rate constants were calculated (Fig. 8).
Increasing the temperature increased the iron removal rate constant while the presence of manganese in the solution decreased the iron removal rate constant due to the competition between iron and manganese ions. The results also showed higher iron removal rate constants in the limestone filter compared to those of limestone/sandstone.

Analysis of variance (ANOVA) was performed on the iron removal rate constant data using MINITAB Release 14 (MINITAB Inc., State College, PA).

Duncan Multiple range test was also performed on the data to test the differences among the levels of each factor. The ANOVA results (Table 4) showed that the 
filter type, solution type and temperature have significant effects on the removal rate constants $(\mathrm{P}=$ $0.04,0.005,0.0001$, respectively). The results showed no significant interactions between the factors. The results of Duncan's Multiple Range test (Table 5) showed that the means of the filter types, solution types and temperatures were significantly different from one another at a $95 \%$ confidence level.

Table 4: Analysis of variance of the iron removal rate constant data

\begin{tabular}{lrcccc}
\hline Source & DF & SS & MS & $\begin{array}{c}\text { F- } \\
\text { Value }\end{array}$ & P \\
\hline Total & 15 & 0.08267 & 0.00551 & & \\
Filter Type (F) & 1 & 0.00580 & 0.00580 & 5.32 & 0.0440 \\
Solution Type (S) & 1 & 0.01429 & 0.01429 & 13.11 & 0.0050 \\
Temperature (Te) & 3 & 0.05165 & 0.01721 & 15.78 & 0.0001 \\
F x S & 1 & 0.00323 & 0.00323 & 0.65 & 0.4350 \\
F x Te & 3 & 0.00216 & 0.00072 & 0.25 & 0.8590 \\
S x Te & 3 & 0.00339 & 0.00113 & 0.68 & 0.5880 \\
Error & 10 & 0.01091 & 0.00109 & & \\
DF & & & & &
\end{tabular}

DF $=$ Degrees of Freedom

$\mathrm{SS}=$ Sum of Squares

MS $=$ Mean of Squares

$\mathrm{R}^{2}=0.87$

$\mathrm{CV}=2.55 \%$

Table 5: Differences among the means of the filter types, solution types and temperatures

\begin{tabular}{lccc}
\hline Parameter & $\begin{array}{c}\text { Number of } \\
\text { Observations }\end{array}$ & $\begin{array}{c}\text { Iron } \\
\text { Removal } \\
\text { Rate } \\
\text { Constant }\end{array}$ & $\begin{array}{c}\text { Duncan } \\
\text { Grouping }\end{array}$ \\
\hline $\begin{array}{l}\text { Filter Type } \\
\text { Limestone }\end{array}$ & 8 & -0.159225 & $\mathrm{~A}$ \\
$\quad$ Limestone/Sandstone & 8 & -0.121132 & $\mathrm{~B}$ \\
$\begin{array}{l}\text { Solution Type } \\
\text { Iron }\end{array}$ & 8 & -0.170075 & $\mathrm{~A}$ \\
$\quad$ Iron/Manganese & 8 & -0.110288 & $\mathrm{~B}$ \\
Temperature $\left({ }^{\circ} \mathrm{C}\right)$ & & & \\
5 & 4 & -0.060875 & $\mathrm{~A}$ \\
10 & 4 & -0.121800 & $\mathrm{~B}$ \\
15 & 4 & -0.161500 & $\mathrm{C}$ \\
20 & 4 & -0.216550 & $\mathrm{D}$ \\
\hline
\end{tabular}

Means with the same letter are not significantly different from each other at $95 \%$ confidence level

Although several researchers ${ }^{[10,11]}$ suggested that the use of a mixture of limestone and sandstone to treat iron contaminated wastewater in order to avoid armoring of limestone and to increase the lifetime of the filter, the result obtained from this study showed that increasing the percent of limestone in the filter from $50 \%$ to $100 \%$ increase the iron removal rate constant by $38 \%$. The precipitation reaction of ferric hydroxide $\left(\mathrm{Fe}(\mathrm{OH})_{3}\right)$ produced protons that would consequently decrease the $\mathrm{pH}$ of the solution and increase the solubility of $\mathrm{Fe}(\mathrm{OH})_{3}$. However, in the presence of limestone stone, the protons produced from precipitation reaction were consumed by the calcium carbonate dissolution reaction as shown in the following equation:

$\mathrm{CaCO}_{3}+2 \mathrm{H}^{+} \rightarrow \mathrm{Ca}^{2+}+\mathrm{H}_{2} \mathrm{CO}_{3}$
As the limestone increased, the neutralization capacity of the solution increased (the $\mathrm{pH}$ of the solution increased). The results showed that the higher the $\mathrm{pH}$ of the solution the lower the solubility of $\mathrm{Fe}(\mathrm{OH})_{3}$ and therefore, the higher the removal rate constant.

Sasowsky et al. ${ }^{[11]}$ reported that sandstone has more negative surface charge than limestone. This would indicate that in addition to more rapid aqueous $\mathrm{Fe}^{2+}$ oxidation at $\mathrm{pH}>6.5$ due to increased hydroxide ion, the decrease in zeta potential (i.e. surface charge) with increasing $\mathrm{pH}$ would promote $\mathrm{Fe}^{2+}$ surface reaction. A synergistic effect clearly occurs when limestone and sandstone are mixed, promoting the precipitation of metal oxide on the sandstone, while allowing the limestone to remain uncoated and continue neutralizing the solution.

\section{Manganese}

The manganese concentrations in the water samples obtained after $3 \mathrm{hrs}$ from the limestone filters were $0.25,0.40,0.34$ and $0.56 \mathrm{mg} \mathrm{L}^{-1}$ with average removal efficiencies of $86.11,77.78,80.89$ and $68.89 \%$ for the temperatures of $20,15,10$ and $5^{\circ} \mathrm{C}$, respectively. The manganese concentrations in the water samples obtained after $3 \mathrm{hrs}$ from the limestone/sandstone filters were $0.40,0.46,0.53$ and $0.65 \mathrm{mg} \mathrm{L}^{-1}$ with average total removal efficiencies of $77.78,74.67,70.83$ and $64.11 \%$ for the temperatures of $20,15,10$ and $5^{\circ} \mathrm{C}$, respectively. Most of the manganese (41.61-69.44\%) was removed from solution by the filters within 20 . However, removal of manganese from the solutions containing iron and manganese was lower than that from solutions containing manganese alone.

The manganese removal efficiency decreased as the temperature decreased. However, by the end of the experiment $(180 \mathrm{~min})$. The results should lower manganese removal in the presence of iron. This is because $\mathrm{Fe}^{2+}$ controlled $\mathrm{Mn}$ oxidation rates by contributing electrons to previously precipitated $\mathrm{Mn}$ oxides to produce $\mathrm{Mn}^{2+}$ as reported by Burdige et al. ${ }^{[12]}$. Barton and Karathanasis ${ }^{[13]}$ also reported Mn oxidation inhibition during the presence of $\mathrm{Fe}^{2+}$ within the system. The relatively lower removal efficiencies of manganese observed in this experiment compared to iron show the slow kinetics of $\mathrm{Mn}^{2+}$ oxidation as reported by Stumm and Morgan ${ }^{[14]}$.

According to Stumm and Morgan ${ }^{[14]}$, the oxidation of manganese in surface waters can also be described by Equation 4 . The manganese data were, therefore, fitted into Equation (4) and the manganese removal rate constants were calculated (Fig. 9). Increasing the temperature increased the manganese removal rate constant while the presence of iron in the solution decreased the manganese removal rate constant.

Analysis of variance (ANOVA) was performed on the manganese removal rate constant data using MINITAB Release 14 (MINITAB Inc., State College, 
PA). Duncan Multiple range test was also performed on the data to test the differences among the levels of each factor. The ANOVA results (Table 6) showed that the filter type, solution type and temperature had significant effects on the removal efficiency $(\mathrm{P}=0.05,0.0001$ and 0.001 , respectively). There were no interactions between the factors. The results of Duncan's Multiple Range test (Table 7) showed that the means of the filter types, solution types and temperatures were significantly different from one another at a 95\% confidence level.

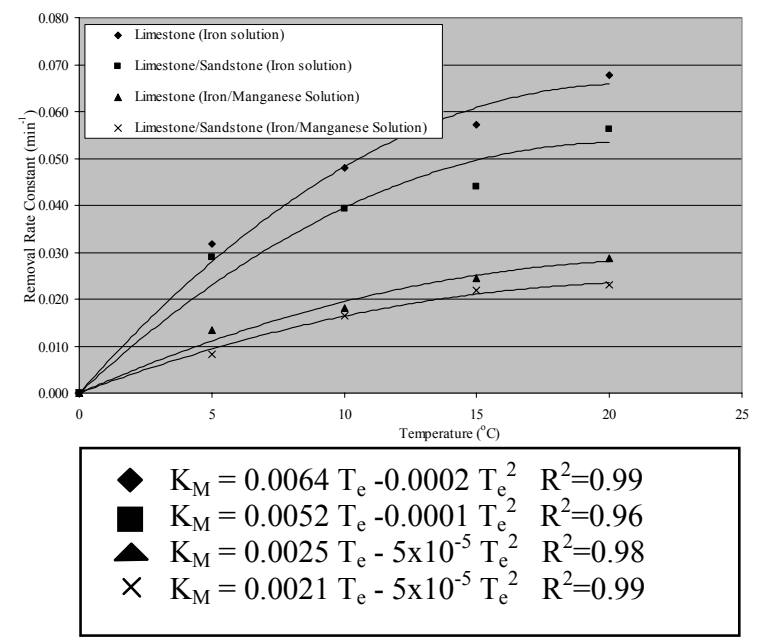

Fig. 9: Temperature effect on manganese removal rate constants

Table 6: Analysis of variance of the manganese removal rate

\begin{tabular}{llccrc} 
Source & DF & SS & MS & $\begin{array}{r}\text { F- } \\
\text { Value }\end{array}$ & P \\
\hline Total & 15 & 0.004572 & 0.000305 & & \\
Filter Type (F) & 1 & 0.000158 & 0.000158 & 7.61 & 0.0200 \\
Solution Type & 1 & 0.003011 & 0.003011 & 144.86 & 0.0001 \\
(S) & & & & \\
Temperature (Te) & 3 & 0.001194 & 0.000398 & 19.15 & 0.0001 \\
F x S & 1 & 0.000026 & 0.000026 & 0.23 & 0.6410 \\
F x Te & 3 & 0.000012 & 0.000003 & 0.01 & 0.9990 \\
S x Te & 3 & 0.000148 & 0.000049 & 1.82 & 0.2220 \\
Error & 10 & 0.000207 & 0.000021 & & \\
DF = Degrees of Freedom & & & \\
SS $=$ Sum of Squares & & & \\
MS $=$ Mean of Squares & & & & \\
$\mathrm{R}^{2}=0.95$ & & & & \\
CV $=1.39 \%$
\end{tabular}

As in the case of iron, the limestone filters had higher removal rate constants than those of limestone/sandstone filters. Increasing the percent of limestone increased the $\mathrm{pH}$ and thus, reduced the solubility of $\mathrm{MnOOH}$ which resulted in a higher removal rate constant. According to Gazea et al. ${ }^{[5]}$, one possible mechanism for abiotic manganese precipitation involves the oxidation of $\mathrm{Mn}^{2+}$ to either $\mathrm{Mn}^{3+}$ or $\mathrm{Mn}^{4+}$, which is similar to ferrous iron oxidation. Then, the
Table 7: Differences among the filter types, solution types and temperatures

\begin{tabular}{lccc}
\hline Parameter & $\begin{array}{c}\text { Number of } \\
\text { Observations }\end{array}$ & $\begin{array}{c}\text { Mn } \\
\text { Removal } \\
\text { Rate } \\
\text { Constant }\end{array}$ & $\begin{array}{c}\text { Duncan } \\
\text { Grouping }\end{array}$ \\
\hline $\begin{array}{l}\text { Filter Type } \\
\text { Limestone }\end{array}$ & 8 & 0.0362 & $\mathrm{~A}$ \\
$\quad$ Limestone/Sandstone & 8 & 0.0299 & $\mathrm{~B}$ \\
$\begin{array}{l}\text { Solution Type } \\
\quad \text { Iron }\end{array}$ & 8 & 0.0467 & $\mathrm{~A}$ \\
$\quad$ Iron/Manganese & 8 & 0.0193 & $\mathrm{~B}$ \\
$\begin{array}{l}\text { Temperature }\left({ }^{\circ} \mathrm{C}\right) \\
5\end{array}$ & 4 & 0.0206 & $\mathrm{~A}$ \\
10 & 4 & 0.0305 & $\mathrm{~B}$ \\
15 & 4 & 0.0369 & $\mathrm{C}$ \\
20 & 4 & 0.0441 & $\mathrm{D}$ \\
\hline
\end{tabular}

Means with the same letter are not significantly different from each other at $95 \%$ confidence level

trivalent $\left(\mathrm{Mn}^{3+}\right)$ or tetravalent $\left(\mathrm{Mn}^{4+}\right)$ form precipitates as $\mathrm{MnOOH}$

In alkaline environments, $\mathrm{Mn}^{2+}$ can also precipitate in the carbonate form, which in the presence of oxygen may also further oxidize to $\mathrm{MnO}_{2}$ as follows:

$\mathrm{Mn}^{2+}+\mathrm{HCO}_{3}^{-} \rightarrow \mathrm{MnCO}_{3(\mathrm{~s})}+\mathrm{H}^{+}$

$\mathrm{MnCO}_{3}+\mathrm{O}_{2} \rightarrow \mathrm{MnO}_{2}+\mathrm{CO}_{2}$

\section{pH}

The initial $\mathrm{pH}$ of the iron, manganese and iron/manganese solutions were $6.1,6.7$ and 6.1 which increased to 7.3-7.8, 7.2-7.8 and 7.20-7.76 during the experiment, respectively. The final $\mathrm{pH}$ values were 7.68-7.76, 7.61-7.69, 7.48-7.58 and 7.26-7.51 for the iron solution, 7.78-7.80, 7.68-7.69, 7.48-7.50 and 7.197.29 for manganese solution and 7.68-7.76, 7.56-7.69, 7.48-7.58 and 7.21-7.51 for the iron/manganese solution at the temperatures of $5,10,15$ and $20^{\circ} \mathrm{C}$, respectively. As $\mathrm{pH}$ of the solution increased, the dissolved iron and manganese concentration decreased. The results showed good correlations $\left(\mathrm{R}^{2}=0.86-0.93\right)$ between the removal efficiencies of iron and the $\mathrm{pH}$ of the solutions in all filters. No consistent correlations were observed between the removal efficiencies of manganese and the $\mathrm{pH}$ of the solution. Correlation between iron removal efficiency and $\mathrm{pH}$ was reported by several authors ${ }^{[6,15]}$. Aziz and Smith ${ }^{[16]}$ and Cravotta and $\operatorname{Trahan}^{[6]}$ found no correlation between the manganese removal efficiency and the $\mathrm{pH}$ of the solution.

During the experiment, the $\mathrm{pH}$ of the water samples did not exceed 7.7. Presently, the $\mathrm{pH}$ of the water in the wetland is approximately neutral. According to Kadlec and Knight ${ }^{[17]}$, many treatment bacteria are not able to survive in highly acidic environments $(\mathrm{pH}<4.0)$ or highly alkaline environments $(\mathrm{pH}>9.5)$. Tanner ${ }^{[18]}$ suggests that the optimum $\mathrm{pH}$ range for treatment wetlands is $3.0<\mathrm{pH}<$ 10.0. Therefore, the wetland ecosystem should be able to adjust to the treated water which has a slightly higher $\mathrm{pH}$ (7.7) without suffering any adverse effects. 


\section{CONCLUSION}

The limestone and limestone/sandstone filters were effective in removing dissolved iron and manganese from landfill leachate under field conditions. The results obtained from these experiments showed that the time and temperature have significant effects on the iron and manganese removal efficiencies. Most of iron was removed from solution within the first $10 \mathrm{~min}$ at $20^{\circ} \mathrm{C}$ while the removal of iron from solution took much longer time $(50 \mathrm{~min})$ at $5^{\circ} \mathrm{C}$. Larger percentage $(69 \%)$ of manganese was removed from solution within the first $20 \mathrm{~min}$ at $20^{\circ} \mathrm{C}$ compared to that $(42 \%)$ removed at $5^{\circ} \mathrm{C}$. Removal of manganese from solution was affected by the presence of iron while presence of manganese did not affect iron removal from solution. The lower removal efficiencies of manganese showed the slow kinetic of manganese oxidation. The iron and manganese removal rate constants of the limestone filters were higher than those of the limestone/sandstone. The $\mathrm{pH}$ of the water samples did not exceed 7.7. Therefore, the wetland ecosystem should be able to adjust to water having a slight alkalinity without suffering adverse effects.

\section{ACKNOWLEDGMENTS}

This research was funded by the EJLB Foundation of Montreal, Quebec, Canada. The financial support provided by Dalhousie University Faculty of Graduate Studies and Faculty of Engineering is highly appreciated.

\section{REFERENCES}

1. Aziz, H.A., M.S. Yusoff, M.N. Adlan, N.H. Adnam and S. Alias, 2004 Physico chemical removal of iron from semi-aerobic landfill leachate by limestone filter. Waste Manag., 24: 353-358.

2. Christensen, T.H., Kjeldsen, P.H.-J. Albrechtsen, G. Heron, P.H. Nielsen, P.L. Bjerg and P.E. Holm, 1994. Attenuation of landfill leachate pollutants in aquifers. Crit. Rev. Environ. Sci. Technol., 24: 119-202.

3. Barlaz, M.A., R.K. Ham and D.M. Schaefer, 1998. Methane production from municipal refuse: A review of enhancement techniques and microbial dynamics. Crit. Rev. Environ. Cont., 19: 557-563.

4. Ziemkiewicz, P.F., J.G. Skousen, D.L. Brant, P.L. Sterner and R.J. Lovett, 1997. Acid mine drainage treatment with armored limestone in open limestone channels. J. Environ. Qual., 26: 10171024.
5. Gazea, B., K. Adam and A. Kontopoulos, 1996. A review of passive systems for the treatment of acid mine drainage. Minerals Engg., 9: 23-42.

6. Cravotta III, C.A. and M.K. Trahan, 1999. Limestone drains to increase $\mathrm{pH}$ and remove dissolved metals from acid mine drainage. Appl. Geochem., 14: 581-606.

7. Hedin, R.S., G.R. Watzlaf and R.W. Nairn, 1994. Passive treatment of acid mine drainage with limestone. J. Environ. Qual., 23: 1338-1345.

8. Kamal, M.A., 2006. Phytoaccumulation of heavy metals by aquatic plants. Ph.D Thesis, Dalhousie University, Halifax, Nova Scotia, Canada.

9. Colorado School of Mines, 1999. Acid Mine Drainage Experiments. Retrieved April 17, 2003 from http://www.mines.edu/fs_home/jhoran/ch126/yello w.htm.

10. Xu, C.Y., F.W. Schwartz and S.J. Traina, 1997. Treatment of acid-mine water with calcite and quartz sand. Environ. Engg. Sci., 14: 141-152.

11. Sasowsky, I.D., A. Foos and C.M. Miller, 2000. Lithic controls on the removal of iron and remediation of acid mine drainage. Water Res., 34: 2742-2746.

12. Burdige, D.J., S.P. Dhakar and K.H. Nealson, 1992. Effects of manganese oxide mineralogy on microbial and chemical manganese reduction. Geomicrob. J., 10: 27-48.

13. Barton, C.D. and A.D. Karathanasis, 1999. Renovation of a failed constructed wetland treating acid mine drainage. Environ. Geol., 39: 39-50.

14. Stumm, W. and G.F. Lee, 1960. The chemistry of aqueous iron. Schweizerische Zeitschruft fur Hydrology 22: 95-139.

15. Wajon, J.E., G.E. Ho and P.J. Murphy, 1985. Rate of precipitation of ferrous iron and formation of mixed iron-calcium carbonates by naturally occurring carbonate materials. Water Res., 19: 831837.

16. Aziz, H.A. and P.G. Smith, 1992. The influence of $\mathrm{pH}$ and coarse media on manganese precipitation from water. Water Res., 26: 853-855.

17. Kadlec, R.H. and R.L. Knight, 1996. Treatment Wetlands. New York: Lewis Publishers.

18. Tanner, C., 2001. Wetlands and aquatic systems for wastewater and stormwater management. Retrieved August 14, 2004 from http:// www.iees.ch/pdf_files/nz01_wetlands_ws.pdf 